\title{
EIF2B2 mutations in vanishing white matter disease hypersuppress translation and delay recovery during the integrated stress response
}

\author{
STEPHANIE L. MOON ${ }^{\mathbf{1}}$ and ROY PARKER ${ }^{1,2}$ \\ ${ }^{1}$ Department of Chemistry and Biochemistry, University of Colorado, Boulder, Colorado 80303, USA \\ ${ }^{2}$ Howard Hughes Medical Institute, University of Colorado, Boulder, Colorado 80303, USA
}

\begin{abstract}
Mutations in eIF2B genes cause vanishing white matter disease (VWMD), a fatal leukodystrophy that can manifest following physical trauma or illness, conditions that activate the integrated stress response (ISR). EIF2B is the guanine exchange factor for eIF2, facilitating ternary complex formation and translation initiation. During the ISR, eIF2 $\alpha$ is phosphorylated and inhibits eIF2B, causing global translation suppression and stress-induced gene translation, allowing stress adaptation and recovery. We demonstrate that VWMD patient cells hypersuppress translation during the ISR caused by acute ER stress, delaying stressinduced gene expression and interrupting a negative feedback loop that allows translational recovery by GADD34-mediated dephosphorylation of phospho-eIF2 $\alpha$. Thus, cells from VWMD patients undergo a prolonged state of translational hyperrepression and fail to recover from stress. We demonstrate that small molecules targeting eIF2B or the elF2 $\alpha$ kinase PERK rescue translation defects in patient cells. Therefore, defects in the ISR could contribute to white matter loss in VWMD.
\end{abstract}

Keywords: white matter disease; eIF2B; GADD34; integrated stress response; ISRIB

\section{INTRODUCTION}

Vanishing white matter disease (VWMD), a fatal leukodystrophy in children and adults, is caused by mutations in any of the five EIF2B genes (Leegwater et al. 2001). VWMD patients often experience episodes of progressive white matter loss following trauma or febrile illnesses (Leegwater et al. 2001). Physical trauma and neuroinflammation can cause ER stress in the brain and activate the integrated stress response (ISR), a pathway that causes global translational suppression and the expression of stress-induced genes (Petrov et al. 2001; Lin et al. 2005; Begum et al. 2014; Chou et al. 2017). EIF2B is an important translation initiation factor that is targeted early in the ISR to mediate the translational repression arm of this pathway. This suggested the hypothesis that disease-causing mutations in EIF2B genes alter the cellular response to stress by perturbing the regulation of translation during the ISR.

The eIF2B complex is a dimer of heteropentamers (Gordiyenko et al. 2014; Kashiwagi et al. 2016) that exchanges GDP for GTP on eIF2 to allow ternary complex formation and translation initiation. During stresses such as viral infections and ER stress, the eIF2 complex is targeted by stress-activated protein kinases that phosphorylate eIF2 $\alpha$ (Hinnebusch

Corresponding author: Roy.Parker@colorado.edu

Article is online at http://www.rnajournal.org/cgi/doi/10.1261/rna.066563. 118. Freely available online through the RNA Open Access option.
1994). Phosphorylated eIF2 $\alpha$ binds the eIF2B complex with higher affinity and represses its exchange activity, leading to reduced ternary complex formation and global translation suppression (Wek et al. 2006). Because fewer translation initiation events take place during the ISR, stress-induced genes that are regulated through upstream open reading frames (uORFs) are selectively translated. These stress-induced genes include ATF4 and CHOP, transcription factors that promote the expression of genes including the eIF2 $\alpha$ phosphatase GADD34, which is one of the feedback mechanisms that facilitate the recovery from stress in the second phase of the ISR (Kojima et al. 2003; Han et al. 2013; Pakos-Zebrucka et al. 2016). As GADD34 is also translationally regulated through uORF mechanisms (Lee et al. 2009), the ISR is governed by coordinated changes in both transcriptional and translational control mechanisms. The coordinated arms of the ISR that facilitate translational repression and stress-induced gene expression are therefore both important for cell survival of stress, and defects in ISR pathway components can cause neurodevelopmental and/or neurodegenerative disorders (Borck et al. 2012; Bruch et al. 2015; Kernohan et al. 2015).

Previous work suggests that defective maturation and cytopathology of astrocytes and oligodendrocytes, the myelinating

(C) 2018 Moon and Parker This article, published in $R N A$, is available under a Creative Commons License (Attribution 4.0 International), as described at http://creativecommons.org/licenses/by/4.0/. 
cells of the brain, may be the cellular basis of VWMD (van der Voorn et al. 2005; van Kollenburg et al. 2006a; Bugiani et al. 2011). Markers of stress-induced translational suppression are elevated in glial cells in VWMD (van der Voorn et al. 2005; van Kollenburg et al. 2006a), and constitutive induction of stress-response pathways in oligodendrocytes recapitulates many aspects of VWMD in a mouse model (Lin et al. 2014). These observations suggest that aberrant stress responses may underlie glial cytopathology in VWMD. However, how disease-causing mutations in VWMD impact the acute stress response is not clear.

We undertook this study to determine if VWMD-causing mutations in EIF2B2, a regulatory subunit of the eIF2B complex, interfered with the cellular response to acute stress, perhaps explaining a key aspect of VWMD: the progressive, episodic loss of white matter in response to trauma or illness. We tested this hypothesis by assessing the translation activity and induction of stress response genes in cell lines derived from VWMD patients and matched controls. Our findings suggest that mutations in EIF2B2 causative of VWMD uncouple the two arms of the ISR by hypersuppressing translation initiation activity during stress, suppressing stress-induced genes including GADD34 to disrupt a negative feedback loop necessary for the adaptation to and recovery from stress.

\section{RESULTS}

\section{VWMD mutations in EIF2B2 do not decrease bulk translation under normal conditions}

Because the eIF2B complex is important for both normal translation activity and regulation of translation activity during stress, EIF2B mutations causative of VWMD could cause a global reduction in translation activity, and/or perturb the integrated stress response. We addressed these possibilities as follows using three immortalized lymphoblast cell lines derived from patients with VWMD caused by mutations in the EIF2B2 subunit, as compared to three age-, sex- and ethnicity-matched control cell lines (described in Materials and Methods).

Several observations demonstrated that VWMD cell lines had similar levels of bulk translation as control cells in the absence of stress. First, by measuring the incorporation of labeled amino acids into nascent polypeptides, we determined that translation in the absence of stress in control and VWMD cell lines was similar (Fig. 1A). This is similar to previous observations that VWMD cell lines show normal levels of translation in the absence of stress (Kantor et al. 2005; van Kollenburg et al. 2006b; Sekine et al. 2016; Wong et al. 2018). Second, western blot analysis showed the examined EIF2B2 mutations did not reduce the levels of EIF2B2 protein (Fig. 1B) or lead to any consistent changes in the levels of EIF2B1, EIF2B3, EIF2B4, and EIF2B5 proteins (Fig. 1B). Third, using antibodies against phospho-eIF2 $\alpha$ we demonstrated that control and VWMD cell lines had very low and
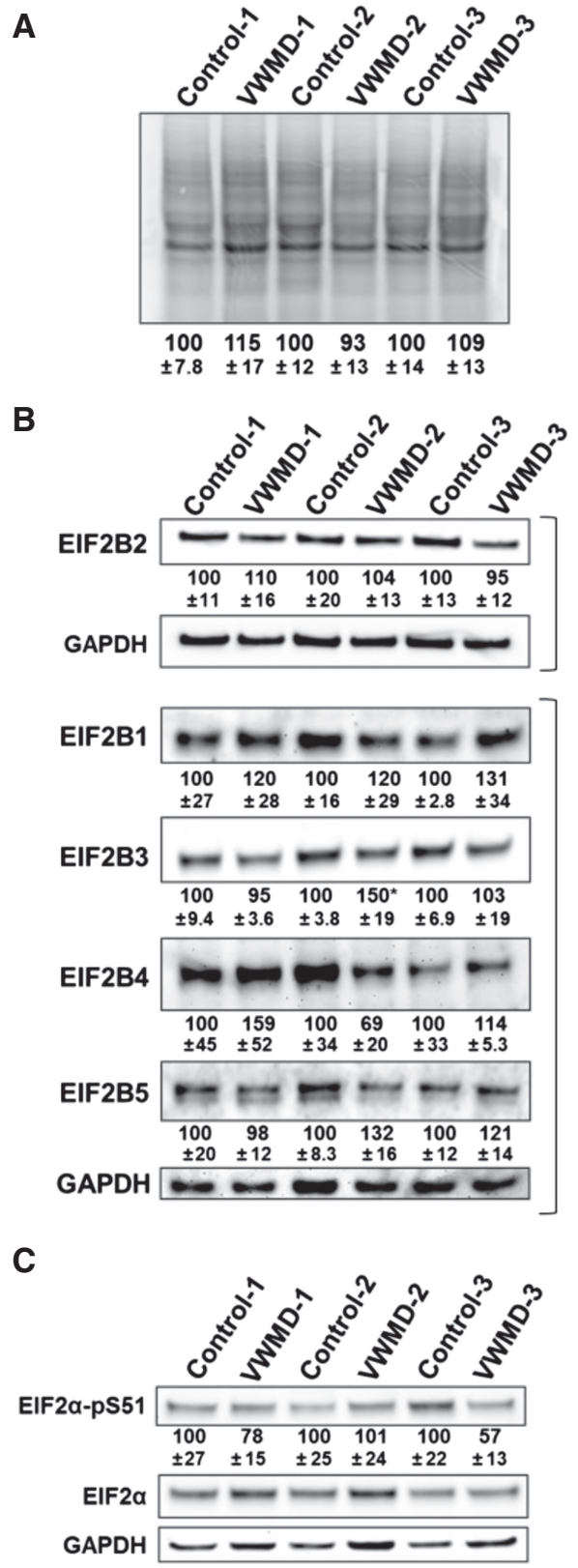

FIGURE 1. VWMD cell lines with EIF2B2 mutations have normal translation activity in unstressed conditions. $(A)$ Equal numbers of control and VWMD patient cell lines were fed ${ }^{35} \mathrm{~S}$-labeled met and cys, lysed and proteins separated on $4 \%-12 \%$ NuPAGE SDS PAGE gels and detected by phosphorimaging. The intensity of each lane was quantified and the averages $\pm S D$ of the lane intensity of each VWMD patient sample relative to the matched control from three independent experiments is shown below a representative gel. (B) The levels of EIF2B1, EIF2B2, EIF2B3, EIF2B4, and EIF2B5 proteins in VWMD patient and control lymphoblasts was assessed by western blotting. Brackets enclose blots for which the indicated EIF2B protein was stripped and reprobed for GAPDH as a loading control. Quantification shows the average relative EIF2B protein levels from three independent experiments \pm SEM below a representative blot. $(C)$ Phospho-eIF2 $\alpha$ levels were determined by western blotting in VWMD patient and matched controls. The average abundance of phospho-eIF2 $\alpha$ ("EIF2 $\alpha$-pS51") relative to total EIF2 $\alpha$ from three independent experiments \pm SEM is shown below a representative blot. Student's $t$-test was used to assess significance in VWMD samples versus control for all experiments. 
similar levels of phospho-eIF2 $\alpha$ in the absence of stress (Fig. 1C). These observations argue that VWMD mutations do not perturb translation or cause a constitutive stress response in the absence of stress.

\section{VWMD patient cell lines hypersuppress translation during acute stress}

We then determined how VWMD mutations affected translation activity during an acute stress response when eIF2BGTP exchange activity is also suppressed by the phosphorylation of eIF2 $\alpha$, and this step becomes limiting for translation initiation activity in the cell. We first measured the degree of translation repression of the control and VWMD cell lines utilizing thapsigargin as a stressor. Thapsigargin induces calcium release from the ER (Thastrup et al. 1990; Lytton et al. 1991), triggering the unfolded protein response (UPR) (McCormick et al. 1997; Pahl 1999), and phosphorylation of eIF2 $\alpha$ by PERK. This is a relevant stress since in VWMD patients, glial cells in the white matter exhibit up-regulated markers of the UPR including phosphorylated PERK and phospho-eIF2a (van der Voorn et al. 2005; van Kollenburg et al. 2006a). Further, traumatic brain injury and interferon- $\gamma$ resulting from neuroinflammation, conditions that trigger white matter loss in VWMD (Leegwater et al. 2001), can cause phosphorylation of eIF2 $\alpha$ and activation of the ISR (Petrov et al. 2001; Lin et al. 2005; Begum et al. 2014; Chou et al. 2017).

An important observation is that all three VWMD patient cell lines repressed translation to a greater degree than control cell lines after 30,45, and $60 \mathrm{~min}$ in the presence of $1 \mu \mathrm{M}$ thapsigargin (Fig. 2A), and the averages of all controls and VWMD cell lines showed greater repression in the VWMD cell lines (Fig. 2B). Similar results are also seen with lower levels of thapsigargin (Supplemental Fig. S1A,B). We also observed that the VWMD cell lines showed stronger translation repression when the UPR is triggered by DTT treatment (Fig. 3C; Supplemental Fig. S2), or arsenite treatment, which causes eIF2 $\alpha$ phosphorylation through the kinase HRI and does not trigger the UPR (Supplemental Fig. S1C,D). These observations indicate that cell lines with EIF2B2 mutations derived from VWMD patients hyperrepress translation during the ISR when EIF2B activity is inhibited by phosphoeIF2a.

Interestingly, the difference in translation activity between VWMD and control cell lines was greater at longer time points post-stress (Fig. 2A,B), suggesting that the VWMD cells could be deficient at triggering the negative feedback loops in the ISR that allow for translation recovery.

\section{VWMD patient cell lines display reduced translation activity during the recovery from acute stress}

One key aspect of the ISR is that it is reversible. The translation that persists when eIF2 $\alpha$ is phosphorylated allows for stress specific translation of ATF4 and other mRNAs, leading to the production of both proteins and the transcription of mRNAs required for recovery from stress. One important stress-induced mRNA is from the GADD34 gene, which produces a phosphatase that acts in a negative feedback loop to dephosphorylate eIF2 $\alpha$ to contribute to translation resumption (Novoa et al. 2001, 2003; Kojima et al. 2003). Therefore, we hypothesized that the hyperrepression of translation in the VWMD cell lines would limit the induction of GADD34 and other proteins required for stress recovery. To examine this possibility, we assessed the ability of VWMD patient cells to resume translation activity following recovery after washing out thapsigargin or DTT after $1 \mathrm{~h}$ of acute ER stress to determine if EIF2B2 mutations limited recovery from stress.

We observed that VWMD patient cells had a significant defect in translation recovery when measured 30 or 60 min after washing out thapsigargin compared to matched controls (Fig. 3A,B). On average, wild-type control cells recovered $38 \pm 2.7 \%$ translation activity and VWMD cells recovered only $14.9 \pm 0.9 \%$ translation activity (an $\sim 2.6$-fold reduction) 60 min after thapsigargin stress. Furthermore, VWMD cell lines also exhibited delayed recovery from stress induced by DTT (Fig. 3C; Supplemental Fig. S2). Taken together, these results indicate that the hypersuppression of translation observed in VWMD patient cells during acute ER stress diminishes the recovery of translation after stress, making the ISR less reversible.

\section{GADD34 expression is delayed in VWMD patient cell lines and associated with prolonged elF2 $\alpha$ phosphorylation}

The defect in recovery from stress seen in the VWMD cells could be explained by a failure to induce the downstream aspects of the ISR, including the GADD34 protein that would dephosphorylate eIF $2 \alpha$ and be one of the feedback loops that contributes to restoring translation. This interpretation predicts that GADD34 protein production should be reduced or delayed in the VWMD cell lines, as it is up-regulated both at the transcription and translation levels during stress (Novoa et al. 2001; Ma and Hendershot 2003; Lee et al. 2009). In addition, due to reduced levels of GADD34, phosphorylated eIF2 $\alpha$ should be expected to be higher and/or persist longer in the VWMD cell lines. To test these predictions, we examined the levels of the stress-induced GADD34 protein by western blotting during thapsigargin stress. We observed a delay in the induction and/or reduction in the amount of GADD34 protein induced by thapsigargin stress in all three VWMD cell lines (Fig. 4A). Comparing the averages of all three cell lines and controls also showed a significant reduction in GADD34 levels in the VWMD cell lines (Fig. 4B). The levels of GADD34 were not significantly different in unstressed conditions in VWMD patient cell lines relative to control cell lines. 
A
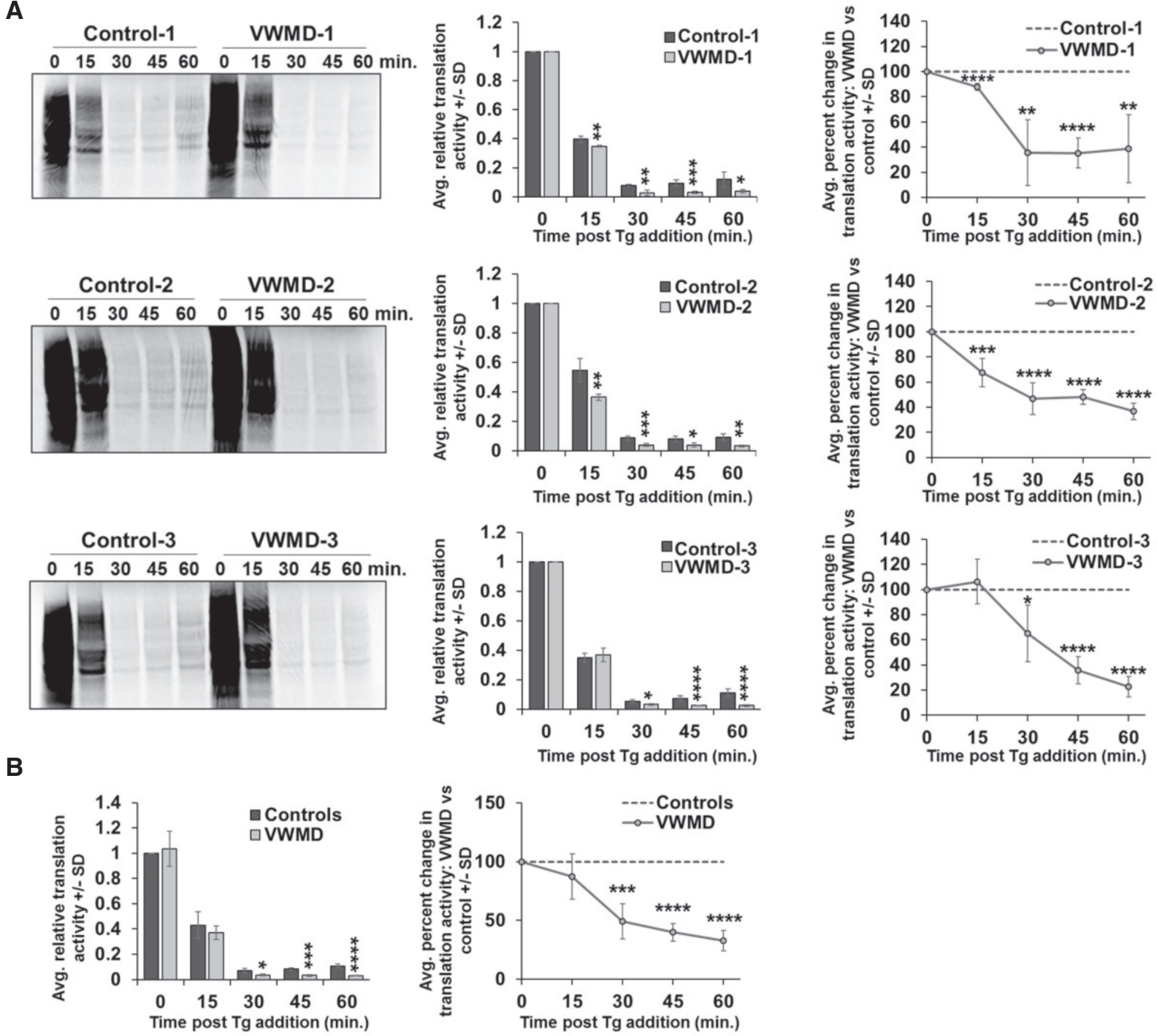

FIGURE 2. Cells from VWMD patients hypersuppress translation during acute stress. (A) Equal numbers of cells from VWMD patient cells and matched controls were treated with $1 \mu \mathrm{M}$ thapsigargin for $0,15,30,45$, or $60 \mathrm{~min}$ and were pulse labeled for 15 min with ${ }^{35} \mathrm{~S}$-met and -cys prior to sample collection. Representative images are shown at left with average translation activity relative to the unstressed time point \pm SD of three experiments presented in the bar graphs. The line graphs represent the average $\pm \mathrm{SD}$ of the percent difference in translation activity at each time point in the indicated VWMD patient cell line relative to the matched control cell line. $(B)$ The average \pm SD of the translation activity from all control and all VWMD patient cell lines relative to the control unstressed condition is depicted in the bar graph at left with the pooled average percent difference in translation activity $\pm \mathrm{SD}$ shown in the line graph at right. Student's $t$-test was done to test significance between control and VWMD samples at each time point, with $\left(^{*}\right)$ indicating $P \leq 0.05,\left({ }^{* *}\right) P \leq 0.01,\left({ }^{* * *}\right) P \leq 0.005$, and $\left({ }^{* * *}\right) P \leq 0.001$.

The reduced GADD34 induction in the VWMD cell lines corresponded with a larger increase, and prolonged persistence, in its target phospho-eIF2 $\alpha$ during thapsigargin stress (Fig. 4C,D). Therefore, increased phospho-eIF2a levels could contribute to failure of these cells to maintain some translation activity during and after acute stress. Of note, lossof-function mutations in GADD34 also increase phosphoeIF2 $\alpha$ levels and block stress-induced gene expression (Novoa et al. 2003). Thus, EIF2B2 mutations causative of VWMD uncouple the translation and stress response gene induction arms of the ISR by hyperrepressing translation and limiting or delaying stress-induced gene expression.

\section{Pharmacological rescue of translation defects in cells derived from VWMD patients}

The hyperrepression of translation due to the EIF2B2 mutations in the VWMD cell lines might contribute to disease phenotypes (see Discussion). Given this, we tested if compounds targeting aspects of the ISR could restore translation in the VWMD cell lines to levels seen in normal cells during an acute stress response. For this experiment, we examined ISRIB, which targets eIF2B to increase its guanine exchange activity on eIF2 (Sidrauski et al. 2013; 2015; Sekine et al. 2015) and the PERK inhibitor I (PERKi) (GSK2606414) 
A
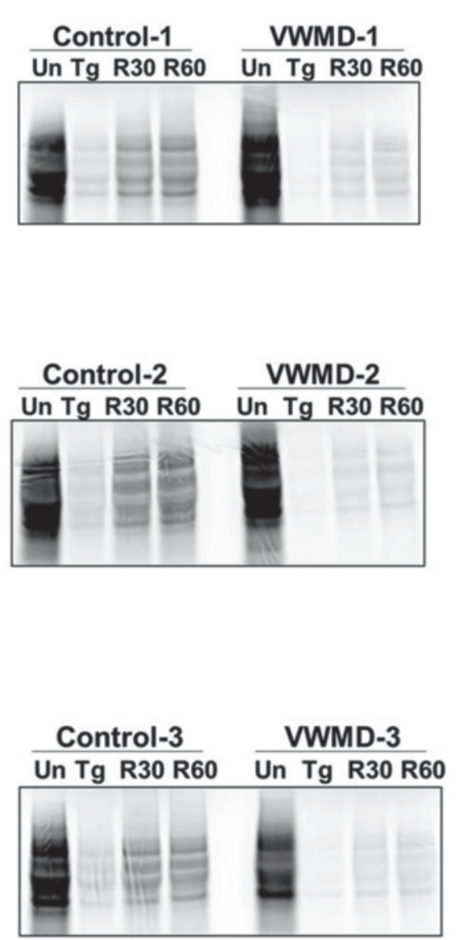

B

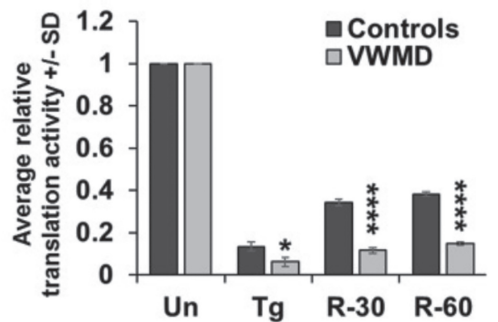

C

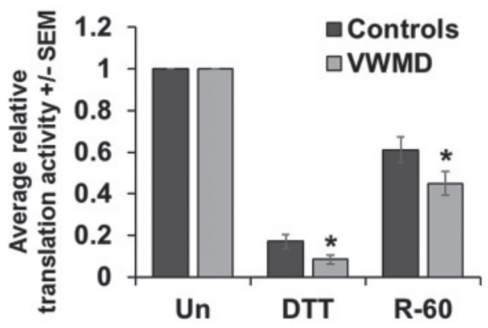

$B$
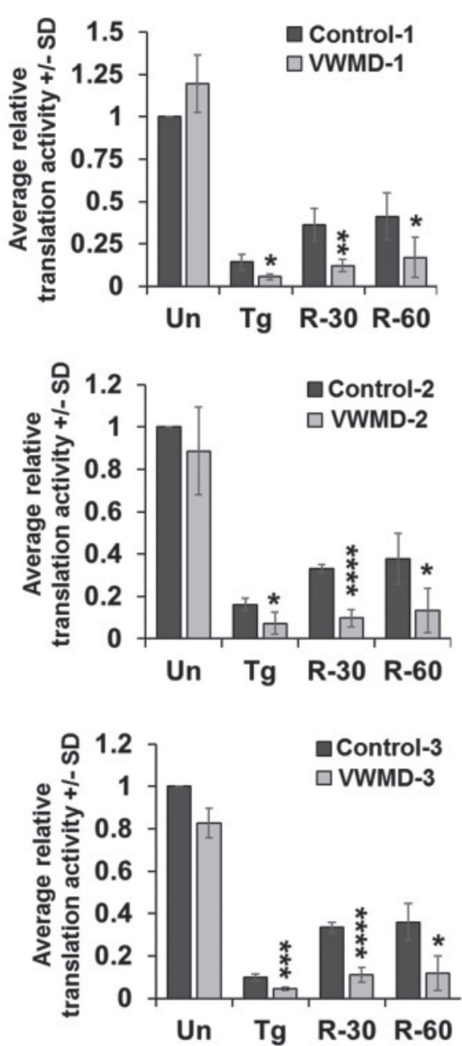
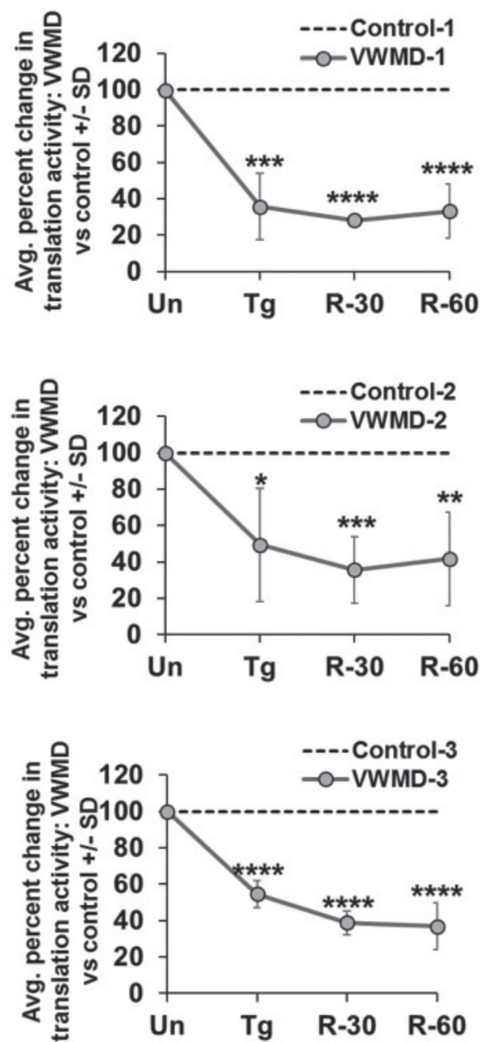

FIGURE 3. VWMD patient cells have limited recovery of translation activity after acute ER stress. $(A)$ Equal numbers of cells from matched controls and VWMD patients were untreated ("Un"), treated with $1 \mu \mathrm{M}$ thapsigargin for $1 \mathrm{~h}$ ("Tg"), or treated with thapsigargin for $1 \mathrm{~h}$, then washed twice and allowed to recover for 30 ("R-30") or 60 ("R-60") min. Representative phosphorimages are shown at left, with bar graphs depicting average \pm SD relative to the control unstressed condition and line graphs showing the average $\pm \mathrm{SD}$ in percent change in translation activity at each time point in VWMD patient cells relative to control cells. $(B)$ The average \pm SD of the translation activity in all pooled VWMD and control cells relative to the unstressed "Un" condition is shown in the bar graph, and the line graph represents the average percent difference \pm SD of the pooled translation activity in the VWMD patient samples relative to controls in each condition. (C) Equal numbers of cells from VWMD patients and matched controls were untreated ("Un") or treated with $2 \mathrm{mM} \mathrm{DTT}$ for $1 \mathrm{~h}$ and collected (“DTT") or washed twice and allowed to recover for $60 \mathrm{~min}$ ("R-60"). Cells were fed ${ }^{35} \mathrm{~S}$ met and cys for $30 \mathrm{~min}$ prior to collection. The average translation activity and percent difference in translation activity $\pm \mathrm{SEM}$ is shown from the pooled VWMD and patient cell lines as in $B$, with the results from the individual matched VWMD and control pairs shown in Supplemental Figure S2. Results represent three to four independent experiments. Student's $t$-test was used to assess significance between VWMD and control samples, with $\left(^{*}\right)$ indicating $P \leq 0.05,\left({ }^{* *}\right) P \leq 0.01,\left({ }^{* *}\right) P \leq 0.005$, and $(* * * *) P \leq 0.001$. 

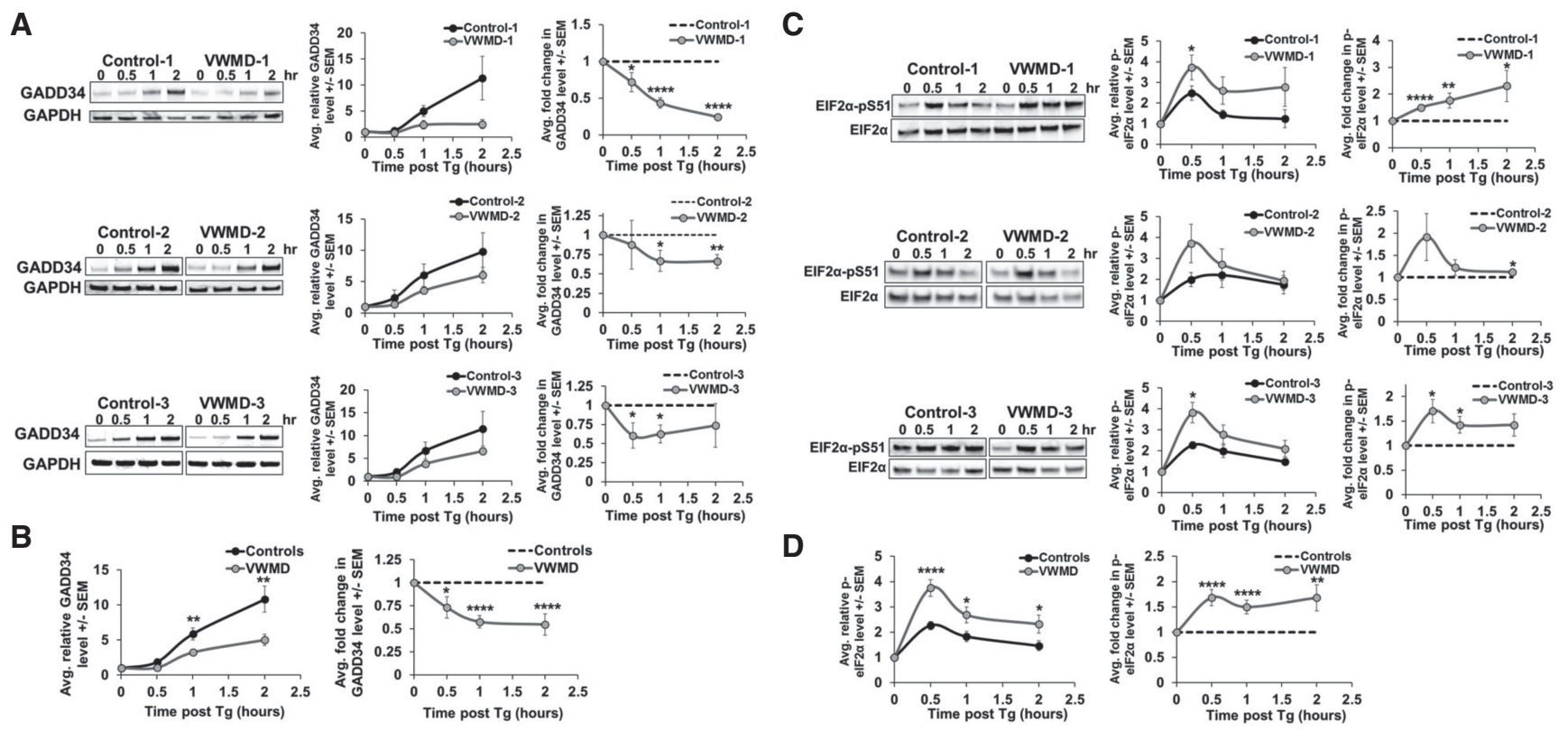

FIGURE 4. The induction of the stress-induced phosphatase GADD34 is delayed, and levels of its target phospho-eIF2 $\alpha$ are increased in VWMD patient cell lines during thapsigargin stress. Equal numbers of VWMD and control cell lines were treated with $1 \mu \mathrm{M}$ thapsigargin for $0,0.5,1$, or $2 \mathrm{~h}$. Western blotting was done to detect GADD34 and the loading control GAPDH $(A, B)$ or phospho-eIF2 $\alpha$ and total eIF2 $\alpha$ (C,D). Representative blots are shown, and the average abundance or fold change in GADD34 $(A)$ or phospho-eIF2 $\alpha(C) \pm$ SEM from three to four independent experiments are depicted in the graphs at right. The pooled average levels and fold change in GADD34 $(B)$ or phospho-eIF2 $\alpha(D)$ in all controls and VWMD patient cell lines are shown \pm SEM. Results represent three to four independent experiments, and Student's $t$-test was used to assess significance between VWMD and control samples, with $\left({ }^{*}\right)$ indicating $P \leq 0.05,\left({ }^{* *}\right) P \leq 0.01,\left({ }^{* * *}\right) P \leq 0.005$, and $\left({ }^{* * * *}\right) P \leq 0.001$.

(Axten et al. 2012). Both ISRIB and PERKi significantly increased translation activity during thapsigargin-mediated ER stress in a dose-dependent manner, although neither drug allowed full recovery of translation activity at the highest concentrations tested (ISRIB at $100 \mathrm{nM}$ and PERKi at $1 \mu \mathrm{M}$ ) in both VWMD and control lymphoblast cell lines (Fig. 5A,B, top panels). We tested a range of ISRIB and PERKi concentrations and determined that low levels of these compounds could rescue the hypersuppression of translation observed in VWMD patient cell lines to the levels observed in healthy control cell lines during stress (Fig. 5). Cells from healthy controls recovered more translation activity in the presence of ISRIB or PERKi than cells from VWMD patients, supporting the idea that eIF2B activity is somewhat compromised in cells with EIF2B2 mutations. These results indicate that eIF2B activity may be increased to normal levels seen in a stress response in VWMD cells by therapeutic intervention that either limits the levels of phosphorylated eIF $2 \alpha$ or interferes with the interaction between phospho-eIF2 $\alpha$ and eIF2B, such that VWMD stress-induced hypersuppression of translation is ameliorated.

\section{Cells with VWMD-causing EIF2B2 (E213G/E304X) mutations are hypersensitive to chronic ER stress}

The defect in the ISR in the VWMD cell lines raised the possibility that cells with VWMD mutations might be more sensitive to stress conditions. To examine this possibility, we tested the ability of immortalized lymphocytes from VWMD patients or matched controls to survive in the presence of thapsigargin, as long-term ER stress causes cell death (Sano and Reed 2013). We observed that the VWMD patient cell lines harboring EIF2B2 (E231G/E304X) mutations (VWMD-1 and VWMD-2) were hypersensitive to prolonged treatment with high amounts of thapsigargin (Fig. 6), as assessed by changes in cellular ATP content, an excellent proxy for cell viability (Petty et al. 1995). Interestingly, the "VWMD-3" cell line (EIF2B2 [S171F/M203X]) was not more sensitive to chronic ER stress and was isolated from a patient with less severe disease progression than the hypersensitive cell lines from "VWMD-1" and "VWMD-2" patients (Fogli et al. 2003 , 2004). We also observed that lower levels of thapsigargin did not cause an appreciable change in cell viability over $24 \mathrm{~h}$ in any of the cells lines (not shown). This suggests that cells with strong VWMD mutations are more sensitive to high levels of chronic stress, which might contribute to disease progression in patients (see discussion).

\section{DISCUSSION}

A key issue in understanding VWMD is determining how the mutations in eIF2B subunits affect translation and thereby contribute to disease progression. Several observations from the literature and this work demonstrate that the mutations in EIF2B genes do not affect bulk translation in the absence of stress. Specifically, we observe that cells with VWMD 
A
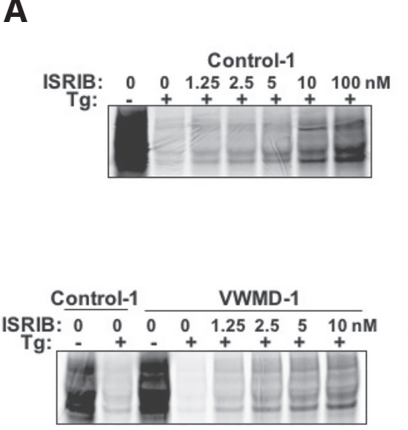
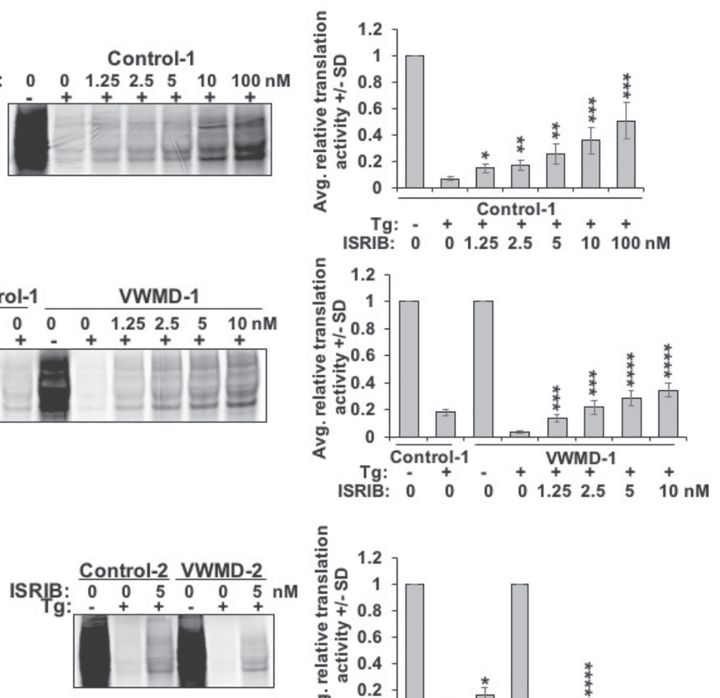

들
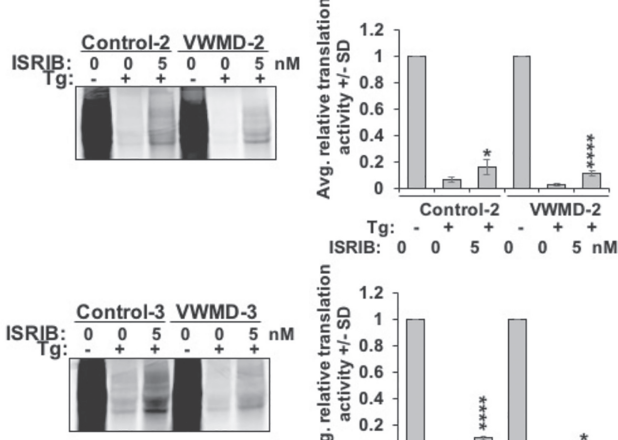

을

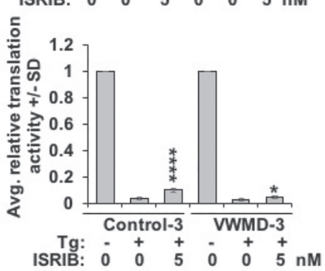

B
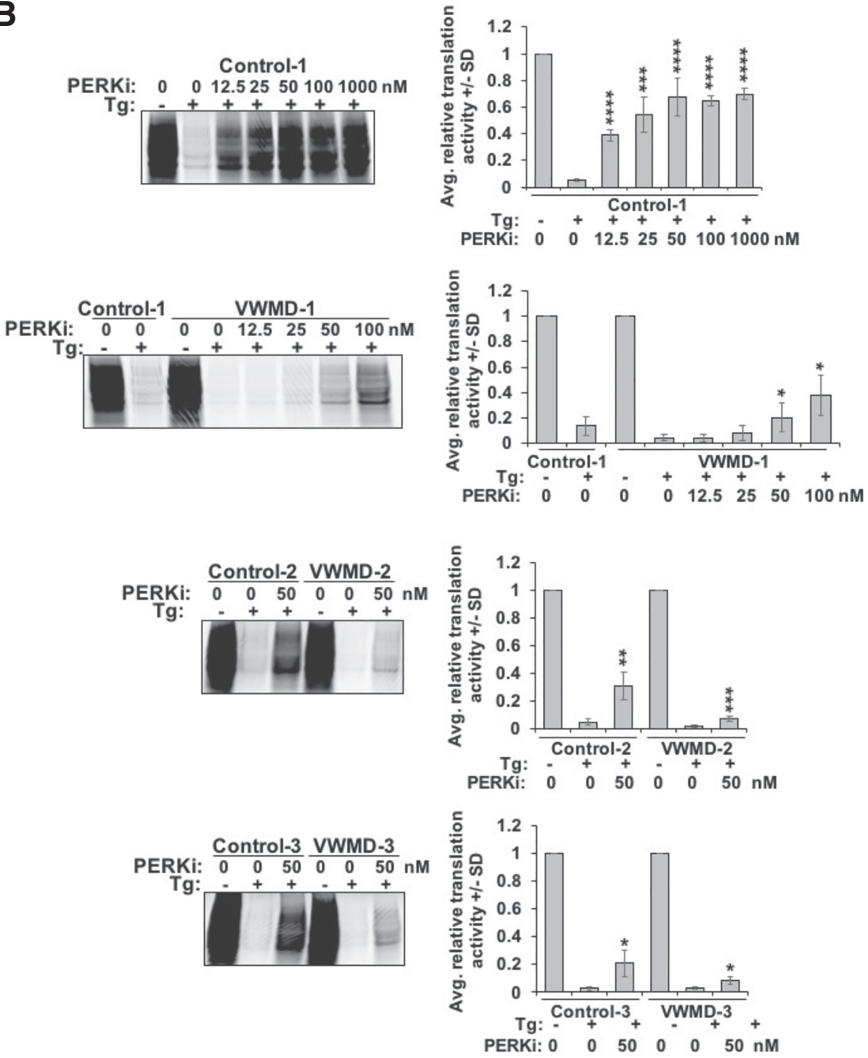

FIGURE 5. Chemical modulators of eIF2B and PERK activity rescue the hypersuppression of translation in VWMD patient cells during stress. (A) Control-1 and VWMD-1 lymphoblasts were incubated with ("+") or without ("-") $1 \mu \mathrm{M}$ thapsigargin ("Tg") in the presence or absence of ISRIB at $0,1.25,2.5,5,10$, or $100 \mathrm{nM}$ for $1 \mathrm{~h}$ and were labeled with ${ }^{35} \mathrm{~S}$-met and -cys for $30 \mathrm{~min}$ prior to lysis and separation on SDS-PAGE gels and phosphorimaging (top two panels). Cells from Control-2, VWMD-2, Control-3, and VWMD-3 were treated as above, only using 0 or $5 \mathrm{nM} \mathrm{ISRIB} \mathrm{(bot-}$ tom two panels). (B) The PERK inhibitor GSK2606414 ("PERKi") was tested at 0, 12.5, 25, 50, 100, or $1000 \mathrm{nM}$ as in $A$ in Control-1 and VWMD-1 lymphoblasts (top two panels). Cells from Control-2, VWMD-2, Control-3, and VWMD-3 were treated as above using 0 or $50 \mathrm{nM} \mathrm{PERKi} \mathrm{(bottom} \mathrm{pan-}$ els). Representative phosphorimages are shown at left and the graphs depict the average \pm SD from three experiments. Student's $t$-tests were done by comparing the drug-treated samples with the samples treated with thapsigargin alone, with $\left(^{*}\right)$ indicating $P \leq 0.05 ;\left({ }^{* *}\right) P \leq 0.01,\left({ }^{* * *}\right) P \leq 0.005$, and $(* * *) P \leq 0.001$.

mutations translate at similar levels as normal control cells (Fig. 1). Similar results have been seen with other VWMD alleles, and in different cellular contexts (Kantor et al. 2005; van Kollenburg et al. 2006b; Sekine et al. 2016; Wong et al. 2018). The normal levels of bulk translation in VWMD cells occur despite clear data that many VWMD mutations reduce the exchange rate of GDP for GTP on eIF2 $\alpha$ (van Kollenburg et al. 2006b; Horzinski et al. 2010; Liu et al. 2011; Wortham and Proud 2015; Wong et al. 2018). This implies that under normal growth conditions the GDP-GTP exchange rate for eIF2 $\alpha$ is not rate-limiting for bulk translation. Thus, the impact of VWMD on translation is not a general reduction in translation rate under all conditions, which is consistent with the birth and initial viability of classical VWMD patients.

We present several observations demonstrating that at least the VWMD mutations in EIF2B2 examined herein alter the cellular response to stress by hyperrepression of translation during a strong stress, and a defect in the recovery of translation during the recovery phase of a stress response. First, we observed that VWMD cells hyperrepress translation in response to thapsigargin, DTT, or arsenite (Figs. 2, 3; Supplemental Figs. S1, S2). Second, we observed that during later time points in a stress response, control cells began to recover translation while VWMD cells did not (Fig. 2). Third, during recovery from thapsigargin or DTT stress we observed that VWMD cells recovered at slower rates and to a lower degree than control cells (Fig. 3; Supplemental Fig. S2). Fourth, we observed that the induction of the GADD34 phosphatase, which dephosphorylates eIF2 $\alpha$ to contribute to translation restoration during stress recovery, is delayed and occurs to a lower extent during acute ER stress in VWMD patient cell lines (Fig. 4A,B), which explains the persistence of phospho-eIF2 $\alpha$ during stress recovery in the VWMD cell lines (Fig. 4C,D). We interpret these observations to suggest that the VWMD variant eIF2B complex is sufficient in unstressed cells to enable adequate GTP exchange on eIF2 $\alpha$ for bulk translation initiation. However, during stress when eIF2 $\alpha$ is phosphorylated, the VWMD variant eIF2B forms are unable to allow sufficient GTP exchange on eIF2 $\alpha$, leading to hyperrepression of translation and perturbation of a negative 

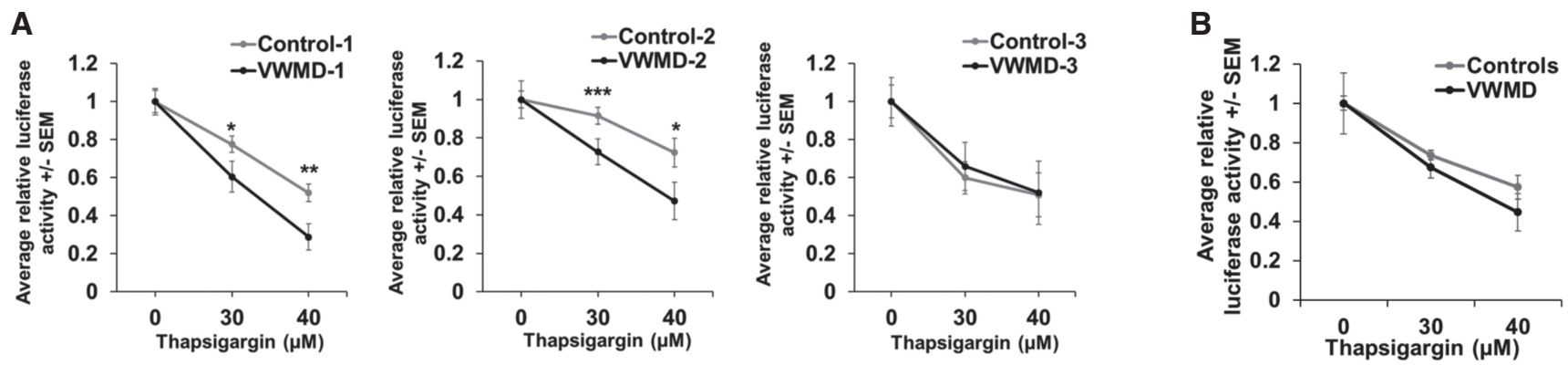

FIGURE 6. VWMD patient lymphocytes with $E I F 2 B 2^{E 213 G / E 304 X}$ mutations are hypersensitive to severe chronic thapsigargin stress. Immortalized lymphoblasts from matched control and VWMD patient cell lines with EIF2B2 mutations were treated with 0,30 , or $40 \mu \mathrm{M}$ thapsigargin for $24 \mathrm{~h}$. Cellular ATP content was then measured as a proxy for cell viability. The results of each matched VWMD and Control cell line are presented in $A$, and the average viability of pooled controls and VWMD patient cell lines shown in $B$. The average \pm SEM from four to six experiments is shown, and Student's $t$-test was used to assess significance, with $\left({ }^{*}\right) P \leq 0.05,\left({ }^{* *}\right) P \leq 0.01$, and $\left({ }^{* * *}\right) P \leq 0.005$.

feedback loop that relies on sufficient induction of GADD34 gene expression during acute stress. This insight provides a possible mechanistic basis for classical VWMD pathogenesis wherein patients exhibit episodic white matter loss following trauma or illnesses that activate cellular stress response pathways in the brain.

Additional observations in the literature argue that other VWMD mutations lead to hypersuppression of translation during acute stress, although this affect has not been explicitly noted. Three previous studies demonstrated a stronger suppression of translation activity in EIF2B mutant cell lines during weak acute ER stresses that caused a reduction in global translation activity in control cells to only $\sim 30 \%-50 \%$ that of unstressed cells. First, fibroblasts derived from VWMD patients with EIF2B4 and EIF2B5 mutations on average displayed an almost significant $(P=0.0500005$, Student's $t$ test) $\sim 50 \%$ reduction in translation activity compared to $\sim 40 \%$ suppression of translation in control cells (Kantor et al. 2005). Second, Sekine et al. (2016) assessed translation activity in Eif2b4-mutant $\mathrm{CHO}$ cells during an acute thapsigargin stress, and these cells also on average exhibited lower translation activity $(\sim 60 \%-70 \%$ suppression in the mutant cell line versus $\sim 50 \%$ suppression in the wild-type cells). Finally, while DTT stress reduced translation to $\sim 30 \%$ in control 293T cell lines, translation was hyperrepressed to $\sim 15 \%$ in isogenic 293T cell lines carrying VWMD mutations in EIF2B1, EIF2B4, or EIF2B5 (Wong et al. 2018). These results suggest that hyperrepression of translation during acute stress may be a common response in cells with VWMD mutations. This suggests a parsimonious model for how VWMD mutations propagate their effects wherein weak hypomorphic alleles of eIF2B are sufficient to allow normal translation, under conditions where eIF2B function is not limiting, but in specific cellular contexts, or stress responses, the diminished eIF2B function is not sufficient to allow residual translation during stress, leading to a failure to properly execute aspects of the ISR.

It has been noted that during a 30-min severe heat stress $\left(44^{\circ} \mathrm{C}\right)$, translation in four different VWMD patient lympho- blasts was reduced to similar levels as a single healthy control cell pool ( $\sim 20 \%$ the activity in unstressed cells) (van Kollenburg et al. 2006b). However, it is possible that no differences were observed in this study because severe heat stress causes translational suppression through the inhibition of translation elongation (Shalgi et al. 2013), not by targeting of translation initiation mediated by eIF2B activity. Therefore, sensitivity to stresses that cause robust phosphorylation of eIF2 $\alpha$ and the ISR could be a common mechanism of many VWMD cases that should be explored further in the future.

The ISR involves additional feedback loops that allow cells to adapt, particularly in chronic stress conditions. For example, during prolonged ER stress translation can resume even in the presence of continued eIF $2 \alpha$ phosphorylation in a manner strongly dependent on eIF3 (Guan et al. 2017). Similarly, constitutive high expression of a misfolded protein in the ER leads to a compensatory ER expansion and an increase in the ER localized chaperone, BiP (Bakunts et al. 2017). Since these additional feedback loops will also require new protein synthesis during conditions of stress and eIF2 phosphorylation, VWMD mutations may also prevent these feedback loops from occurring due to reduced translation during the initial stress conditions, which can be examined in future experiments.

The observation that the two arms of the acute ISR response- translation repression and transcriptional activation of stress response genes-can be partially uncoupled by naturally occurring mutations in EIF2B genes that cause VWMD is important for two main reasons. First, white matter loss is a facet of many other neurodegenerative disorders including Alzheimer's disease, and occurs to some degree with normal aging (Double et al. 1996; Cardenas et al. 2007). Aberrant regulation of the ISR could be a generalizable mechanism for white matter loss in other myelin disorders. For example, mutations in the gene encoding CReP, a constitutively expressed phosphatase that dephosphorylates phospho-eIF2a in unstressed conditions and during acute ER stress (Jousse et al. 2003), cause developmental delays in white matter 
myelination in addition to microcephaly, short stature and learning disability (Kernohan et al. 2015). Dysregulation of the UPR and ER stress pathways may also contribute to several other genetic myelin disorders including Charcot-MarieTooth neuropathies (Volpi et al. 2017), indicating that targeting the ISR could serve as a useful treatment strategy for many diseases. It is also possible that dysregulation of the ISR might contribute to other aspects of VWMD including cataracts, as elevated levels of phospho-eIF2 $\alpha$ are observed in human lens samples from patients with congenital cataracts (Yang et al. 2015). We suggest that ISRIB, PERK inhibitors, and potentially other small molecules that target the translational repression arm of the ISR could be used as a therapeutic option for VWMD, as we have demonstrated their utility in scaling back the translation repression threshold observed in patient cell lines during stress (Fig. 5). Moreover, recent work has provided additional biochemical evidence that ISRIB can rescue the function of eIF2B complexes with VWMD alleles (Wong et al. 2018). Since we observed that $1.25 \mathrm{nM}$ ISRIB was sufficient in VWMD cell lines to restore translation during stress to control levels, one possible therapeutic approach may be to use very low doses of an ISRIB-like molecule to restore eIF2B function sufficiently during stress conditions, which might limit potential toxic side effects.

In addition to VWMD mutations causing a more robust and prolonged ISR, evidence in the literature suggests VWMD mutations will potentially affect translation in three other manners. First, one anticipates a lower level of GTP exchange activity caused by EIF $2 B$ mutations would suggest that cells with low eIF2 $\alpha$ phosphorylation, which would not normally be sufficient to trigger a stress response in cells, might trigger the ISR. Evidence for this possibility comes from the observation that low levels of thapsigargin trigger a more robust induction of ATF4 in VWMD patient cells than control cells (Kantor et al. 2005). Second, the reduced guanine exchange factor activity due to VWMD might be low enough to fail to support full translation under conditions with increased demand for translation. In support of this possibility, in response to LPS treatment astrocytes in mouse models of VWMD fail to fully induce cytokines and chemokines needed for astrogliosis and remyelination (Cabilly et al. 2012). Finally, one has to anticipate that the translation rate of some specific mRNAs will be sensitive to even partial reduction in eIF2B function, and therefore VWMD cells will have alterations in their proteome, which is supported by an altered proteome in VWMD cells, and brains from VWMD mice as compared to control samples (Gat-Viks et al. 2015; Raini et al. 2017). This diversity of differences in translation suggests that VWMD could arise by a complex mixture of these different alterations. For example, the hyperrepression of translation during stress may trigger more cellular apoptosis and demyelination during trauma or infections, followed by an inability of astrocytes to properly activate astrogliosis and remyelination. Future examination of how these perturbations occur in animal models and/or in neuronal cells, particularly glia, derived from human inducible pluripotent stem cells and contribute to disease progression will be important, particularly considering that neuronal cell types could display a differential sensitivity to chronic stresses as compared to immortalized cell lines used in this and other studies.

Our results suggest that hypersuppression of translation disrupts a negative feedback loop wherein GADD34 is rapidly induced and dephosphorylates phospho-eIF2 $\alpha$ to allow translation resumption for recovery or to engage in a chronic ER stress response in part through genes induced transcriptionally by CHOP, ATF3, and ATF4. Future work should aim to determine how VWMD patient cell lines respond to chronic stress and how the temporal regulation of stress-induced gene expression is affected by various EIF2B mutations. For example, a recent study (Sekine et al. 2016) demonstrated that mutations in Eif2b4 analogous to those found in VWMD patients cause increased expression of a $\mathrm{CHOP}$ reporter protein after $24 \mathrm{~h}$ of chronic ER stress, and elevated levels of CHOP, BiP, and GADD34 mRNA were present in brain tissue from VWMD patients harboring mutations in EIF2B5 and EIF2B2 subunits (van Kollenburg et al. 2006a). However, other studies have concluded there are few differences in the levels of stress-induced genes in VWMD patient cells compared to controls (Horzinski et al. 2010). It should be determined if contradictory results in the literature regarding this problem are explained by effects of different VWMD-causing mutations, the time and severity of the stressor, or the cell type. A detailed analysis of the kinetics of stress-induced gene expression at the levels of transcription and translation over the course of acute and chronic ER stress responses could illuminate how changes in translation regulation during the acute phase of the ISR might impact the chronic stress response and/or identify any compensatory mechanisms that might facilitate a proper chronic stress response in the face of an aberrant acute stress response. Further, elucidating which stress-induced genes are affected at the level of transcription by global translation hypersuppression as occurs in these VWMD patient cell lines could yield important insights into how stress-induced genes are regulated for proper dynamic control of the stress response.

\section{MATERIALS AND METHODS}

\section{Lymphoblast cultures}

Immortalized lymphocytes from three VWMD patients and three age-, ethnicity- and sex-matched apparently healthy controls were obtained from the Coriell Biorepository (Table 1). Cells were maintained in RPMI 1640 (GibcoTM) with 15\% fetal bovine serum (FBS; Atlas Biologicals) and $1 \%$ streptomycin/penicillin in suspension flasks at $37^{\circ} \mathrm{C}$ under $5 \% \mathrm{CO}_{2}$.

\section{Western blotting}

To assess specific protein levels, equal numbers of patient lymphoblasts or matched controls were incubated in the presence or 
TABLE 1. The following cell lines used in this study were obtained from the NIGMS Human Genetic Cell Repository at the Coriell Institute for Medical Research

\begin{tabular}{llllll}
\hline Label (this study) & ID number & Ethnicity & Sex & Age (yr) & EIF2B2 mutation \\
\hline VWMD-1 & GM20073 & Caucasian & F & 24 & 638A >G (E213G), 910G>C (E304X) \\
VWMD-2 & GM20074 & Caucasian & M & 21 & 638A $>$ G (E213G), 910G >C (E304X) \\
VWMD-3 & GM19988 & Caucasian & F & 36 & 512C>T (S171F), 607_613delinsTG (M203X) \\
Control-1 & GM05377 & Caucasian & F & 24 & N/A \\
Control-2 & GM16118 & Caucasian & M & 21 & N/A \\
Control-3 & GM14807 & Caucasian & F & 35 & N/A \\
\hline
\end{tabular}

absence of $1 \mu \mathrm{M}$ thapsigargin for $0.5,1$, or $2 \mathrm{~h}$ at $37^{\circ} \mathrm{C}$ and lysed using NP-40 cell lysis buffer $(50 \mathrm{mM}$ Tris- $\mathrm{HCl}$ pH 8.0, $150 \mathrm{mM}$ $\mathrm{NaCl}, 0.5 \% \mathrm{NP}-40$ substitute, $5 \mathrm{mM}$ EDTA) or RIPA buffer $(50$ $\mathrm{mM}$ Tris- $\mathrm{HCl} \mathrm{pH} 8,150 \mathrm{mM} \mathrm{NaCl}, 1 \% \mathrm{NP}-40$ substitute, $0.5 \%$ deoxycholate, $0.1 \%$ SDS plus $0.1 \mathrm{U} / \mu \mathrm{L}$ Turbo DNase) and phosphatase/protease inhibitor cocktail (Cell Signaling Technology). Protein concentrations were determined using the Bradford protein assay (Bio-Rad), and equal amounts of protein were loaded on $4 \%-$ $12 \%$ NuPAGE protein gels (Thermo Fisher Scientific). Proteins were transferred to nitrocellulose membranes and probed for GAPDH (Cell Signaling Technology 3683), EIF2B1 (Thermo Fisher Scientific PA5-28992), EIF2B2 (Proteintech 50-555-431), EIF2B3 (Santa Cruz Biotechnology sc-166768), EIF2B4 (Santa Cruz Biotechnology sc-28855), EIF2B5 (H-9; Santa Cruz Biotechnology sc514056), GADD34 (Proteintech 10449-1-AP), EIF2a (Cell Signaling Technology 9722), or phospho-EIF2 $\alpha$ (Abcam ab32157) with antirabbit (Cell Signaling Technology 7074) or anti-mouse (Sigma-Aldrich A4416) HRP-conjugated secondary antibodies. Proteins were detected using SuperSignal West Dura extended duration or Femto Maximum sensitivity substrate (Thermo Fisher Scientific) for chemiluminescent imaging. Membranes were stripped using OneMinute Advance WB Stripping Buffer (GM Biosciences) to reprobe for loading controls. Relative protein abundances are reported from three to four independent experiments compared to GAPDH and relative phospho-eIF2 $\alpha$ levels were determined relative to total eIF $2 \alpha$ on the same blot.

\section{Metabolic labeling of nascent proteins during and after stress}

Protein biosynthesis was assessed in human lymphoblasts in the presence and absence of stress using ${ }^{35} \mathrm{~S}$-incorporated methionine and cysteine (EXPRE35S35S Protein Labeling Mix, PerkinElmer). Equal numbers $\left(1 \times 10^{6}\right)$ of lymphoblasts were washed once with RPMI 1640 lacking cysteine and methionine (Sigma-Aldrich) with $15 \%$ dialyzed FBS (Sigma-Aldrich) and 1\% streptomycin/penicillin and incubated for $15 \mathrm{~min}$ at $37^{\circ} \mathrm{C}$ to deplete internal amino acid stores. To assess translation activity during thapsigargin stress, enough thapsigargin (Calbiochem) to reach $0,0.125,0.25,0.5$, or $1 \mu \mathrm{M}$ was added to each sample and incubated for $30 \mathrm{~min}$ at $37^{\circ} \mathrm{C}$. Approximately $10 \mu \mathrm{Ci}{ }^{35} \mathrm{~S}$-labeled met/cys was added to each sample and incubated $30 \mathrm{~min}$ at $37^{\circ} \mathrm{C}$ prior to sample collection. For stress time-course experiments, cells were incubated in the presence or absence of $1 \mu \mathrm{M}$ thapsigargin or $0.5 \mathrm{mM}$ sodium arsenite, and metabolic labeling was done for 15 (thapsigargin stress) or 30 (arsenite stress) minutes immediately prior to sample collec- tion. Translation recovery assays were done by incubating samples for $1 \mathrm{~h}$ in the presence or absence of $1 \mu \mathrm{M}$ thapsigargin or $2 \mathrm{mM}$ DTT in complete cys- and met-depleted RPMI then washing twice with complete medium via successive 5-min centrifugations at 500 rcf. Samples were then resuspended in complete cys-/met- depleted RPMI. Approximately $10 \mu \mathrm{Ci}^{35} \mathrm{~S}$-labeled cys/met was added immediately after washing, or after $30 \mathrm{~min}$ to enable 30 -min labeling periods for recovery after $30 \mathrm{~min}$ ("R-30") and $60 \mathrm{~min}$ ("R-60") poststress. Cells were pelleted and stored at $-80^{\circ} \mathrm{C}$, then lysed in NP-40 lysis buffer with protease inhibitor cocktail (Sigma-Aldrich). Insoluble materials were removed by centrifugation and equal volumes of lysate were heat-denatured and run on $4 \%-12 \%$ NuPAGE protein gels (Thermo Fisher Scientific). Gels were exposed to phosphor screens and imaged using the Typhoon FLA 9500 phosphorimager. ImageJ was used to quantify signal intensity in each lane and the translation activity in each cell line in the presence of thapsigargin relative to the unstressed condition was determined. Results shown are the average $\pm \mathrm{SD}$ of three or four independent experiments with significance assessed by Student's $t$-test.

\section{Drug treatments}

To determine the effect of drugs acting on the PERK-eIF2 pathway on translation activity, equal numbers of lymphoblasts were either untreated, treated with $1 \mu \mathrm{M}$ thapsigargin, or $1 \mu \mathrm{M}$ thapsigargin plus trans-ISRIB (Fisher Scientific), or PERK inhibitor I (GSK2606414; EMD Millipore). Samples were incubated in the presence or absence of $1 \mu \mathrm{M}$ thapsigargin and each drug as above for $1 \mathrm{~h}$ at $37^{\circ} \mathrm{C}$ and labeled with ${ }^{35} \mathrm{~S}$ - met and cys for $30 \mathrm{~min}$ immediately prior to collection. ISRIB was tested at $1.25,2.5,5,10$, and $100 \mathrm{nM}$ and PERK inhibitor I tested at $12.5,25,50,100$, and $1000 \mathrm{nM}$ concentrations. The average \pm SD of nascent protein signal from SDS-PAGE gels and phosphorimaging as described above from three independent experiments is reported. Significance was determined using Student's $t$-test.

\section{Lymphocyte viability assays}

Equal numbers of immortalized lymphocytes were seeded into 96well flat-bottom white plates in duplicate or triplicate wells in the presence or absence of thapsigargin (Calbiochem) at 30 or $40 \mu \mathrm{M}$. Cells were incubated for $24 \mathrm{~h}$ and ATP was measured as a proxy for cell viability using the Promega CellTiter-Glo 2.0 assay with the GloMax-Multi Detection System (Promega). The results of four or six independent biological replicates are reported \pm SEM and significance was assessed by $t$-test. 


\section{SUPPLEMENTAL MATERIAL}

Supplemental material is available for this article.

\section{ACKNOWLEDGMENTS}

We thank Denise Muhlrad and Dr. Anjali Rao for technical assistance, members of the Parker laboratory, especially Dr. Carolyn Decker, for helpful comments and advice, and the Cell Culture Facility at the BioFrontiers Institute. S.L.M. was funded by the Anna and John J. Sie Foundation post-doctoral fellowship award. This work was supported by funds to R.P. from the Howard Hughes Medical Institute.

Author contributions: S.L.M. and R.P. conceptualized the work and arranged the methodology; S.L.M. performed the formal analysis and investigation; S.L.M. and R.P. wrote the original draft and then reviewed and edited it; R.P. supervised the work.

Received March 24, 2018; accepted April 7, 2018.

\section{REFERENCES}

Axten JM, Medina JR, Feng Y, Shu A, Romeril SP, Grant SW, Li WH, Heerding DA, Minthorn E, Mencken T, et al. 2012. Discovery of 7-methyl-5-(1-\{[3-(trifluoromethyl)phenyl $]$ acetyl $\}-2,3$-dihydro-1Hindol-5-yl)-7H-pyrrolo[2,3-d]pyrimidin-4-amine (GSK2606414), a potent and selective first-in-class inhibitor of protein kinase $R$ (PKR)-like endoplasmic reticulum kinase (PERK). J Med Chem 55: 7193-7207.

Bakunts A, Orsi A, Vitale M, Cattaneo A, Lari F, Tadè L, Sitia R, Raimondi A, Bachi A, van Anken E. 2017. Ratiometric sensing of $\mathrm{BiP}$-client versus $\mathrm{BiP}$ levels by the unfolded protein response determines its signaling amplitude. Elife 6: 27518.

Begum G, Yan HQ, Li L, Singh A, Dixon CE, Sun D. 2014. Docosahexaenoic acid reduces ER stress and abnormal protein accumulation and improves neuronal function following traumatic brain injury. J Neurosci 34: 3743-3755.

Borck G, Shin BS, Stiller B, Mimouni-Bloch A, Thiele H, Kim JR, Thakur M, Skinner C, Aschenbach L, Smirin-Yosef P, et al. 2012. eIF2 $\gamma$ mutation that disrupts eIF2 complex integrity links intellectual disability to impaired translation initiation. Mol Cell 48: 641-646.

Bruch J, Kurz C, Vasiljevic A, Nicolino M, Arzberger T, Höglinger GU. 2015. Early neurodegeneration in the brain of a child without functional PKR-like endoplasmic reticulum kinase. J Neuropathol Exp Neurol 74: 850-857.

Bugiani M, Boor I, van Kollenburg B, Postma N, Polder E, van Berkel C, van Kesteren RE, Windrem MS, Hol EM, Scheper GC, et al. 2011. Defective glial maturation in vanishing white matter disease. J Neuropathol Exp Neurol 70: 69-82.

Cabilly Y, Barbi M, Geva M, Marom L, Chetrit D, Ehrlich M, ElroyStein O. 2012. Poor cerebral inflammatory response in eIF2B knock-in mice: implications for the aetiology of vanishing white matter disease. PLoS One 7: e46715.

Cardenas VA, Boxer AL, Chao LL, Gorno-Tempini ML, Miller BL, Weiner MW, Studholme C. 2007. Deformation-based morphometry reveals brain atrophy in frontotemporal dementia. Arch Neurol 64: 873-877.

Chou A, Krukowski K, Jopson T, Zhu PJ, Costa-Mattioli M, Walter P, Rosi S. 2017. Inhibition of the integrated stress response reverses cognitive deficits after traumatic brain injury. Proc Natl Acad Sci 114: E6420-E6426.

Double KL, Halliday GM, Kril JJ, Harasty JA, Cullen K, Brooks WS, Creasey H, Broe GA. 1996. Topography of brain atrophy during normal aging and Alzheimer's disease. Neurobiol Aging 17: 513-521.
Fogli A, Rodriguez D, Eymard-Pierre E, Bouhour F, Labauge P, Meaney BF, Zeesman S, Kaneski CR, Schiffmann R, BoespflugTanguy O. 2003. Ovarian failure related to eukaryotic initiation factor 2B mutations. Am J Hum Genet 72: 1544-1550.

Fogli A, Schiffmann R, Bertini E, Ughetto S, Combes P, EymardPierre E, Kaneski CR, Pineda M, Troncoso M, Uziel G, et al. 2004. The effect of genotype on the natural history of eIF2B-related leukodystrophies. Neurology 62: 1509-1517.

Gat-Viks I, Geiger T, Barbi M, Raini G, Elroy-Stein O. 2015. Proteomics-level analysis of myelin formation and regeneration in a mouse model for Vanishing White Matter disease. J Neurochem 134: 513-526.

Gordiyenko Y, Schmidt C, Jennings MD, Matak-Vinkovic D, Pavitt GD, Robinson CV. 2014. eIF2B is a decameric guanine nucleotide exchange factor with a $\gamma 2 \varepsilon 2$ tetrameric core. Nat Commun 5: 3902.

Guan BJ, van Hoef V, Jobava R, Elroy-Stein O, Valasek LS, Cargnello M, Gao XH, Krokowski D, Merrick WC, Kimball SR, et al. 2017. A unique ISR program determines cellular responses to chronic stress. Mol Cell 68: 885-900.e6.

Han J, Back SH, Hur J, Lin YH, Gildersleeve R, Shan J, Yuan CL, Krokowski D, Wang S, Hatzoglou M, et al. 2013. ER stress-induced transcriptional regulation increases protein synthesis leading to cell death. Nat Cell Biol 15: 481-490.

Hinnebusch AG. 1994. The eIF-2 a kinases: regulators of protein synthesis in starvation and stress. Semin Cell Biol 5: 417-426.

Horzinski L, Kantor L, Huyghe A, Schiffmann R, Elroy-Stein O, Boespflug-Tanguy O, Fogli A. 2010. Evaluation of the endoplasmic reticulum-stress response in eIF2B-mutated lymphocytes and lymphoblasts from CACH/CVWM patients. BMC Neurol 10: 94.

Jousse C, Oyadomari S, Novoa I, Lu P, Zhang Y, Harding HP, Ron D. 2003. Inhibition of a constitutive translation initiation factor $2 a$ phosphatase, CReP, promotes survival of stressed cells. J Cell Biol 163: 767-775.

Kantor L, Harding HP, Ron D, Schiffmann R, Kaneski CR, Kimball SR, Elroy-Stein O. 2005. Heightened stress response in primary fibroblasts expressing mutant eIF2B genes from CACH/VWM leukodystrophy patients. Hum Genet 118: 99-106.

Kashiwagi K, Takahasi M, Nishimoto M, Hiyama TB, Higo T, Umehara T, Sakamoto J, Ito T, Yokoyama S. 2016. Crystal structure of eukaryotic translation initiation factor 2B. Nature 531: 122-125.

Kernohan KD, Tétreault M, Liwak-Muir U, Geraghty MT, Qin W, Venkateswaran S, Davila J, Care4Rare Canada Consortium, Holcik M, Majewski J, et al. 2015. Homozygous mutation in the eukaryotic translation initiation factor $2 a$ phosphatase gene, PPP1R15B, is associated with severe microcephaly, short stature and intellectual disability. Hum Mol Genet 24: 6293-6300.

Kojima E, Takeuchi A, Haneda M, Yagi A, Hasegawa T, Yamaki K, Takeda K, Akira S, Shimokata K, Isobe K. 2003. The function of GADD34 is a recovery from a shutoff of protein synthesis induced by ER stress: elucidation by GADD34-deficient mice. FASEB J 17: 1473-1475.

Lee YY, Cevallos RC, Jan E. 2009. An upstream open reading frame regulates translation of GADD34 during cellular stresses that induce eIF2a phosphorylation. J Biol Chem 284: 6661-6673.

Leegwater PA, Vermeulen G, Könst AA, Naidu S, Mulders J, Visser A, Kersbergen P, Mobach D, Fonds D, van Berkel CG, et al. 2001. Subunits of the translation initiation factor eIF2B are mutant in leukoencephalopathy with vanishing white matter. Nat Genet 29: 383-388.

Lin W, Harding HP, Ron D, Popko B. 2005. Endoplasmic reticulum stress modulates the response of myelinating oligodendrocytes to the immune cytokine interferon- $\gamma$. J Cell Biol 169: 603-612.

Lin Y, Pang X, Huang G, Jamison S, Fang J, Harding HP, Ron D, Lin W. 2014. Impaired eukaryotic translation initiation factor $2 \mathrm{~B}$ activity specifically in oligodendrocytes reproduces the pathology of vanishing white matter disease in mice. J Neurosci 34: 12182-12191.

Liu R, van der Lei HD, Wang X, Wortham NC, Tang H, van Berkel CG, Mufunde TA, Huang W, van der Knaap MS, Scheper GC, et al. 2011. Severity of vanishing white matter disease does not correlate with 
deficits in eIF2B activity or the integrity of eIF2B complexes. Hum Mutat 32: 1036-1045.

Lytton J, Westlin M, Hanley MR. 1991. Thapsigargin inhibits the sarcoplasmic or endoplasmic reticulum Ca-ATPase family of calcium pumps. J Biol Chem 266: 17067-17071.

Ma Y, Hendershot LM. 2003. Delineation of a negative feedback regulatory loop that controls protein translation during endoplasmic reticulum stress. J Biol Chem 278: 34864-34873.

McCormick TS, McColl KS, Distelhorst CW. 1997. Mouse lymphoma cells destined to undergo apoptosis in response to thapsigargin treatment fail to generate a calcium-mediated grp78/grp94 stress response. J Biol Chem 272: 6087-6092.

Novoa I, Zeng H, Harding HP, Ron D. 2001. Feedback inhibition of the unfolded protein response by GADD34-mediated dephosphorylation of eIF2 $\alpha$. J Cell Biol 153: 1011-1022.

Novoa I, Zhang Y, Zeng H, Jungreis R, Harding HP, Ron D. 2003. Stressinduced gene expression requires programmed recovery from translational repression. EMBO J 22: 1180-1187.

Pahl HL. 1999. Signal transduction from the endoplasmic reticulum to the cell nucleus. Physiol Rev 79: 683-701.

Pakos-Zebrucka K, Koryga I, Mnich K, Ljujic M, Samali A, Gorman AM. 2016. The integrated stress response. EMBO Rep 17: 1374-1395.

Petrov T, Underwood BD, Braun B, Alousi SS, Rafols JA. 2001. Upregulation of iNOS expression and phosphorylation of eIF-2a are paralleled by suppression of protein synthesis in rat hypothalamus in a closed head trauma model. J Neurotrauma 18: 799-812.

Petty RD, Sutherland LA, Hunter EM, Cree IA. 1995. Comparison of MTT and ATP-based assays for the measurement of viable cell number. J Biolumin Chemilumin 10: 29-34.

Raini G, Sharet R, Herrero M, Atzmon A, Shenoy A, Geiger T, ElroyStein O. 2017. Mutant eIF2B leads to impaired mitochondrial oxidative phosphorylation in vanishing white matter disease. J Neurochem 141: 694-707.

Sano R, Reed JC. 2013. ER stress-induced cell death mechanisms. Biochim Biophys Acta 1833: 3460-3470.

Sekine Y, Zyryanova A, Crespillo-Casado A, Fischer PM, Harding HP, Ron D. 2015. Stress responses. Mutations in a translation initiation factor identify the target of a memory-enhancing compound. Science 348: $1027-1030$.

Sekine Y, Zyryanova A, Crespillo-Casado A, Amin-Wetzel N, Harding HP, Ron D. 2016. Paradoxical sensitivity to an integrated stress response blocking mutation in vanishing white matter cells. PLoS One 11: e166278.
Shalgi R, Hurt JA, Krykbaeva I, Taipale M, Lindquist S, Burge CB. 2013. Widespread regulation of translation by elongation pausing in heat shock. Mol Cell 49: 439-452.

Sidrauski C, Acosta-Alvear D, Khoutorsky A, Vedantham P, Hearn BR, Li H, Gamache K, Gallagher CM, Ang KK, Wilson C, et al. 2013. Pharmacological brake-release of mRNA translation enhances cognitive memory. Elife 2: e00498.

Sidrauski C, Tsai JC, Kampmann M, Hearn BR, Vedantham P, Jaishankar P, Sokabe M, Mendez AS, Newton BW, Tang EL, et al. 2015. Pharmacological dimerization and activation of the exchange factor eIF2B antagonizes the integrated stress response. Elife 4: e07314.

Thastrup O, Cullen PJ, Drøbak BK, Hanley MR, Dawson AP. 1990. Thapsigargin, a tumor promoter, discharges intracellular $\mathrm{Ca}^{2+}$ stores by specific inhibition of the endoplasmic reticulum $\mathrm{Ca}^{2+}$-ATPase. Proc Natl Acad Sci 87: 2466-2470.

van der Voorn JP, van Kollenburg B, Bertrand G, Van Haren K, Scheper GC, Powers JM, van der Knaap MS. 2005. The unfolded protein response in vanishing white matter disease. J Neuropathol Exp Neurol 64: 770-775.

van Kollenburg B, van Dijk J, Garbern J, Thomas AA, Scheper GC, Powers JM, van der Knaap MS. 2006a. Glia-specific activation of all pathways of the unfolded protein response in vanishing white matter disease. J Neuropathol Exp Neurol 65: 707-715.

van Kollenburg B, Thomas AA, Vermeulen G, Bertrand GA, van Berkel CG, Pronk JC, Proud CG, van der Knaap MS, Scheper GC. 2006b. Regulation of protein synthesis in lymphoblasts from vanishing white matter patients. Neurobiol Dis 21: 496-504.

Volpi VG, Touvier T, D’Antonio M. 2017. Endoplasmic reticulum protein quality control failure in myelin disorders. Front Mol Neurosci 9: 162.

Wek RC, Jiang HY, Anthony TG. 2006. Coping with stress: eIF2 kinases and translational control. Biochem Soc Trans 34: 7-11.

Wong YL, LeBon L, Edalji R, Lim HB, Sun C, Sidrauski C. 2018. The small molecule ISRIB rescues the stability and activity of Vanishing White Matter Disease eIF2B mutant complexes. Elife 7: e32733.

Wortham NC, Proud CG. 2015. eIF2B: recent structural and functional insights into a key regulator of translation. Biochem Soc Trans 43: 1234-1240.

Yang J, Zhou J, Gu Y, Wang M, Guo Y, Liu Y. 2015. Differences in unfolded protein response pathway activation in the lenses of three types of cataracts. PLoS One 10: e0130705. 

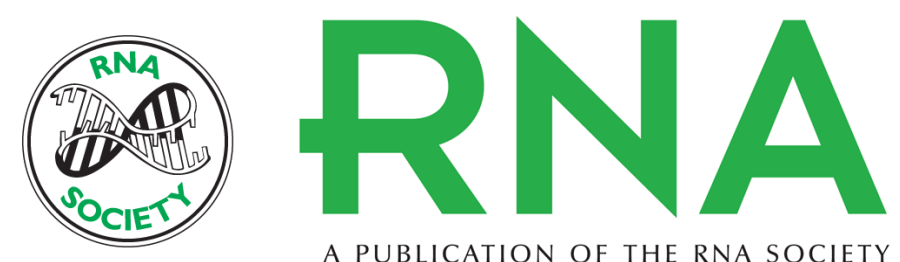

A PUBLICATION OF THE RNA SOCIETY

\section{EIF2B2 mutations in vanishing white matter disease hypersuppress translation and delay recovery during the integrated stress response}

Stephanie L. Moon and Roy Parker

RNA 2018 24: 841-852 originally published online April 9, 2018

Access the most recent version at doi:10.1261/rna.066563.118

\section{Supplemental http://rnajournal.cshlp.org/content/suppl/2018/04/02/rna.066563.118.DC1 Material}

References This article cites 53 articles, 16 of which can be accessed free at: http://rnajournal.cshlp.org/content/24/6/841.full.html\#ref-list-1

Open Access Freely available online through the RNA Open Access option.

Creative This article, published in $R N A$, is available under a Creative Commons License Commons (Attribution 4.0 International), as described at

License http://creativecommons.org/licenses/by/4.0/.

Email Alerting Receive free email alerts when new articles cite this article - sign up in the box at the Service top right corner of the article or click here.

\section{|||||||| Providing Precise Solutions for your research.}

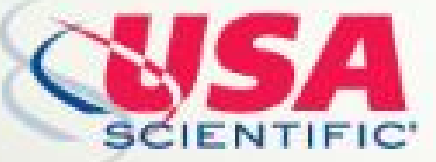

To subscribe to $R N A$ go to:

http://rnajournal.cshlp.org/subscriptions 